\title{
Comparison of Methods for Incorporating a Radioiodinated Residualizing Cholesteryl Ester Analog into Low Density Lipoprotein
}

\author{
LAURA E. DEFORGE ${ }^{1 *}$, MARK R. DEGALAN ${ }^{\dagger} \dagger$, MOHAMED K. RUYAN ${ }^{2}$, \\ ROGER S. NEWTON ${ }^{3}$ and RAYMOND E. COUNSELL ${ }^{1} \ddagger$
}

\begin{abstract}
'Department of Pharmacology and ${ }^{2}$ Interdepartmental Program in Medicinal Chemistry, University of Michigan, Ann Arbor, MI 48109 and ${ }^{3}$ Parke-Davis Pharm. Res. Div., Warner-Lambert Co., Ann Arbor, MI 48105, U.S.A.
\end{abstract}

(Received 13 February 1992)

\begin{abstract}
Two different methods were evaluated for incorporating $\left[{ }^{125} I\right]$ cholesteryl iopanoate $\left.\left.\left({ }^{[25}\right]\right] \mathrm{CI}\right)$, a non-hydrolyzable cholesteryl ester analog, into LDL. The first procedure was an organic solvent delipidation-reconstitution procedure (R[ $\left.\left.{ }^{125} \mathrm{I}-\mathrm{CI}\right] \mathrm{LDL}\right)$ while the second involved incubation of detergent (Tween-20)-solubilized $\left[{ }^{125} \mathrm{I}\right] \mathrm{CI}$ with whole plasma (D $\left[{ }^{125} \mathrm{I}-\mathrm{CI}\right] \mathrm{LDL}$ ). R[ $\left.{ }^{125} \mathrm{I}-\mathrm{CI}\right] \mathrm{LDL}$ behaved similar to native LDL in vitro, but was markedly different in vivo, apparently due to a heterogeneity in particle size. $\mathrm{D}\left[{ }^{125} \mathrm{I}-\mathrm{CI}\right] \mathrm{LDL}$, however, was metabolized normally both in vitro and in vivo. These results, combined with the residualizing nature of $\left[{ }^{125} \mathrm{I}\right] \mathrm{Cl}$, demonstrate that $\mathrm{D}\left[{ }^{125} \mathrm{I}-\mathrm{CI}\right] \mathrm{LDL}$ is appropriate for tracing $\mathrm{LDL}$ uptake in vivo.
\end{abstract}

\section{Introduction}

Study of the disposition of low density lipoprotein (LDL)-associated cholesteryl esters (CE) in vivo is complicated by the fact that, once cellular uptake occurs, the lipoprotein constituents are rapidly degraded. The free cholesterol arising from hydrolysis of the $\mathrm{CE}$ can then either undergo re-esterification and remain within the cell as stored cholesteryl ester (Goldstein and Brown, 1977) or it can redistribute to other tissues. This process has particularly hampered biodistribution studies, which are essential in evaluating the alterations in sites of $\mathrm{CE}$ uptake accompanying hypercholesterolemia and treatment with lipid-lowering drugs. For this reason, several investigators have directed their efforts toward developing LDL preparations labeled with radiotracers which residualize in the tissues. Notable examples of LDL labeled on the protein moiety include [99 $\mathrm{m}$ Tc]LDL (Lees et al., 1985; Fischman et al., 1987) and [25 I]tyramine cellobiose-LDL (Pittman et al., 1983). Comparatively little progress, however, has been made with respect to the development of radiolabeled, non-degradable $\mathrm{CE}$ analogs. One compound

Present addresses: *Department of Pathology, University of Michigan Medical School, Ann Arbor, MI 48109 and †Department of Radiology, Indiana University Medical School, Indianapolis, IN 46202, U.S.A.

¥All correspondence should be addressed to: Dr Raymond E. Counsell, M6322 Medical Science Building I, Department of Pharmacology, University of Michigan Medical School, Ann Arbor, MI 48109-0626, U.S.A. of this type is $\left[{ }^{3} \mathrm{H}\right]$ cholesteryl linoleyl ether, which has been used by Stein and coworkers in a variety of studies (Halperin et al., 1986). Alternatively, $\left[{ }^{125} \mathrm{I}\right]$ cholesteryl iopanoate $\left({ }^{125} \mathrm{I}\right] \mathrm{CI}$ ) (Fig. 1), a CE analog used in several studies in our laboratory, has properties which demonstrate its utility as a tracer for lipoprotein metabolism in vivo. First, the compound is quite stable to degradation in vivo (Seevers et al., 1982; DeGalan et al., 1986), and its uptake into tissues has been found to be highly correlated with the tissue CE content (DeGalan et al., 1985; DeForge et al., 1989). In addition, the $\gamma$-emitting isotope simplifies its quantitation in tissue samples and also permits non-invasive assessment of the biodistribution of radioactivity using nuclear medicine imaging techniques such as gamma camera scintigraphy (Counsell et al., 1989; DeGalan et al., 1988; DeForge et al., 1989). Lastly, recent studies in our laboratory have shown $\left[{ }^{125} \mathrm{I}\right] \mathrm{CI}$ to be a poor substrate for human, rabbit, and guinea pig lipid transfer protein (LTP), with a rate of transfer $5-15 \%$ that of $\left[{ }^{3} \mathrm{H}\right]$ cholesteryl oleate (manuscript in preparation). Although this property limits the methods which can be used to

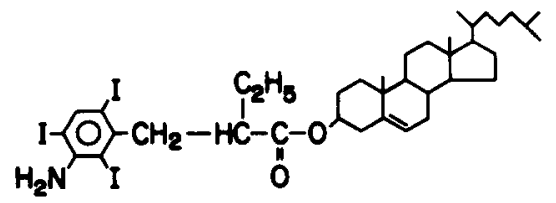

Fig. 1. Structure of cholesteryl iopanoate. Radioiodine is introduced by an exchange reaction with $\mathrm{Na}\left[{ }^{125} \mathrm{I}\right]$. 
incorporate $\left.{ }^{125} \mathrm{I}\right] \mathrm{CI}$ into $\mathrm{LDL}$, it also increases the likelihood that, after injection into animals, the $\left[{ }^{125} \mathrm{I}\right] \mathrm{CI}$ will remain associated with the injected LDL without rapidly redistributing among the endogenous lipoproteins.

In these studies, $\left.{ }^{125} \mathrm{I}\right] \mathrm{CI}$ was incorporated into LDL by two different procedures not requiring LTP involvement. In vitro and in vivo analyses were then used to evaluate the similarity of the resulting preparations to native LDL.

\section{Materials and Methods}

\section{Isolation of low density lipoprotein}

Human $L D L$. Blood $(500 \mathrm{~mL})$ freshly drawn from normal human volunteers was obtained from the University of Michigan Hospital apheresis clinic, and a preservative cocktail was added (Edelstein and Scanu, 1986). Plasma was obtained by low speed centrifugation at $4^{\circ} \mathrm{C}$, and LDL was isolated between the densities of 1.020 and $1.063 \mathrm{~g} / \mathrm{mL}$ as previously described (Havel et al., 1955) using a Beckman L8-80 ultracentrifuge and a $60 \mathrm{Ti}$ rotor. The LDL was dialyzed against $4 \times 4 \mathrm{~L}$ phosphate-buffered saline (PBS) containing $0.01 \%$ EDTA and sterilized by passage through a $0.22 \mu \mathrm{m}$ filter. The protein content was determined by the method of Lowry et al. (1951) using bovine serum albumin (BSA) as a standard.

Guinea pig $L D L$. Male guinea pigs $(350-400 \mathrm{~g})$ were obtained from Hazelton Research Laboratories (Denver, $\mathrm{Pa}$ ). Blood from 4 to 6 animals was drawn from the right atrium into syringes containing preservatives (Edelstein and Scanu, 1986). The blood was pooled, and the procedure described for the isolation of human LDL was then followed, with the exception that the fraction between the densities of 1.020 and $1.100 \mathrm{~g} / \mathrm{mL}$ was harvested as LDL (Guo et al., 1977).

\section{$L D L$ labeling procedures}

Radioiodination of $L D L$. Human and guinea pig LDL were radioiodinated as previously described (Goldstein et al., 1983) using $\mathrm{Na}\left[{ }^{125} 1\right]$ obtained from ICN (Irvine, Calif.). After dialysis against at least 4 changes of buffer ( $4 \mathrm{~L} 0.9 \% \mathrm{NaCl}, 1.5 \mathrm{mM}$ EDTA, $\mathrm{pH} 7.2$ ), greater than $97 \%$ of the $\left.{ }^{125} \mathrm{I}\right] \mathrm{LDL}$ radioactivity was precipitable by $12 \%$ trichloroacetic acid (TCA) and less than $10 \%$ of the radioactivity was extractable in chloroform/methanol $(2: 1)$. Specific activities ranged between 120 and $600 \mathrm{dpm} / \mathrm{ng}$ protein.

Reconstitution of $L D L$. Human and guinea pig LDL were reconstituted essentially as described by Krieger et al. (1978). Briefly, $1.9 \mathrm{mg}$ LDL protein and $25 \mathrm{mg}$ potato starch were mixed in siliconized test tubes, lyophilized overnight, and delipidated with ice-cold heptane over a $1.5 \mathrm{~h}$ incubation period at $-20^{\circ} \mathrm{C}$. The desired mixture of lipids in hexane
( $\leqslant 500 \mu \mathrm{L}$, see below) was then added to the $\mathrm{LDL} /$ starch matrix. Following a $1 \mathrm{~h}$ incubation at $-20^{\circ} \mathrm{C}$, the solvent was completely evaporated under $\mathrm{N}_{2}$ at $0^{\circ} \mathrm{C}$, and $1 \mathrm{~mL} 10 \mathrm{mM}$ Tricine buffer ( $\mathrm{pH} 8.4$ ) was added to each test tube. The reconstituted LDL was separated from the starch by low speed centrifugation after an overnight incubation at $4^{\circ} \mathrm{C}$. Aliquots were analyzed for radioactivity using either a TM Analytic (model 1185) or Micromedic Systems MACC $\gamma$-counter. Protein concentrations were determined as described (Lowry et al., 1951).

The $\left[{ }^{125} \mathrm{I}\right] \mathrm{CI}$ was synthesized and radiolabeled as previously described (Seevers et al., 1982) to obtain specific activities ranging between 0.2 and $1.7 \mathrm{Ci} / \mathrm{mmol}$. Its radiochemical purity was checked prior to use by thin layer chromatography in a hexane/ethyl acetate $(5: 2)$ solvent system using Eastman silica gel chromatographic sheets.

LDL was reconstituted with cholesteryl oleate (CO, Sigma Chemical Co.) mixed with tracer quantities of $\left.{ }^{[25} \mathrm{I}\right] \mathrm{CI}$. Because preliminary studies indicated that reconstitution of LDL with $2 \mathrm{mg}$ of the $\left.{ }^{125} \mathrm{I}\right] \mathrm{CI} / \mathrm{CO}$ mixture per $1.9 \mathrm{mg} \mathrm{LDL}$ protein yielded a preparation with highest specific activity and greatest uptake into fibroblasts, this ratio was used in subsequent studies. As assessed by the analyses described below, the $\left[{ }^{125} \mathrm{I}\right] \mathrm{CI}$-reconstituted LDL was essentially identical to a control preparation of LDL reconstituted with $\left[{ }^{3} \mathrm{H}\right]$ cholesteryl linoleate, using $6 \mathrm{mg}$ total CE per $1.9 \mathrm{mg}$ LDL protein as described by Krieger et al. (1978).

Because of its ready availability, human LDL was used for several studies involving the in vitro characterization of reconstituted LDL. Preparations of reconstituted guinea pig LDL, which were also characterized in vitro to ensure their biologic validity, were used for all in vivo studies. The results of the reconstitution were essentially identical regardless of the species origin of the LDL. Average protein and radioactivity recoveries were 45 and $36 \%$, respectively, and specific activities ranged from 40 to $120 \mathrm{dpm} / \mathrm{mg}$ depending on the specific activity and quantity of $\left[{ }^{125} \mathrm{I}\right] \mathrm{CI}$ used per reconstitution. Reconstituted human and guinea pig LDL will be denoted as $\mathbf{R}\left[{ }^{125} \mathrm{I}-\mathrm{CI}\right] \mathrm{LDL}$ and $\left.\mathbf{R}^{125} \mathrm{I}-\mathrm{Cl}\right] \mathrm{gpLDL}$, respectively, when the distinction is necessary.

Incorporation of detergent-solubilized ${ }^{125}$ ICCI into $L D L$. [ $\left.{ }^{125} \mathrm{I}\right] \mathrm{CI}$ was formulated by adding Tween-20 (100 $\mu \mathrm{L} / \mathrm{mg}$ compound) to the [ $\left.{ }^{125} \mathrm{I}\right] \mathrm{CI}$ dissolved in hexane/ethyl acetate $(19: 1)$. After vortexing thoroughly, the solvents were evaporated under a slow stream of nitrogen. Saline was then added such that the Tween- 20 constituted $\leqslant 3 \%$ of the final volume. The mixture was vortexed thoroughly again and placed briefly under nitrogen to remove any residual solvents. Samples were taken for determination of radioactivity content. Guinea pig plasma was obtained as described above, and an aliquot of the formulated [ $\left.{ }^{125} \mathrm{I}\right] \mathrm{CI}$ was added to a 10 -fold greater volume of plasma. The mixture was then incubated 
at $37^{\circ} \mathrm{C}$ with gentle agitation. A preliminary timecourse study demonstrated maximal association of $\left[{ }^{125} \mathrm{I}\right] \mathrm{CI}$ with the LDL fraction was achieved by a $2-\mathrm{h}$ incubation period. This incubation time was used for all further studies. The $\left.{ }^{125} \mathrm{I}\right] \mathrm{CI}$-labeled $\mathrm{LDL}$ fraction $\left(\mathrm{D}\left[{ }^{125} \mathrm{I}-\mathrm{CI}\right] \mathrm{gpLDL}\right.$ ) was then isolated from the plasma by ultracentrifugation as described above. The $\mathrm{D}\left[{ }^{125} \mathrm{I}-\mathrm{CI}\right] \mathrm{gpLDL}$ was then dialyzed against $4 \times 4 \mathrm{~L}$ PBS, and aliquots were analyzed for protein (Lowry et al., 1951) and radioactivity. Recoveries of protein and radioactivity were greater than $90 \%$ and approx. $60 \%$, respectively, and specific activities ranged between 30 and $45 \mathrm{dpm} / \mathrm{ng}$ protein. Although this procedure has also been used to label human LDL, it was particularly successful for guinea pig LDL (in terms of $\left[{ }^{125} \mathrm{I}\right] \mathrm{CI}$ recovery) due to the predominance of this lipoprotein fraction in the plasma.

\section{Characterization}

Column chromatography. Samples of the various LDL preparations were adjusted to $10 \% \mathrm{w} / \mathrm{v}$ sucrose, applied to a $2.6 \times 90 \mathrm{~cm}$ column of $6 \%$ agarose (Bio-Gel A-5 m, 200-400 mcsh, Bio-Rad Laboratories, Richmond, Calif.) (Rudel et al., 1974), and eluted with sterile $0.9 \% \mathrm{NaCl} / 0.01 \%$ EDTA at $4^{\circ} \mathrm{C}$. Fractions $(100 \times 250$ drops $)$ were collected under gravity flow (approx. $0.35 \mathrm{~mL} / \mathrm{min}$ ). The eluant was monitored for absorbance at $280 \mathrm{~nm}$, and aliquots of each fraction were taken for determination of radioactivity content. For samples of reconstituted LDL, the fractions representing peaks of protein and radioactivity were pooled, put into dialysis tubing (molecular weight cutoff, 12,000), and concentrated in polyvinyl pyrrolidone (Sigma Chemical Co.). After dialyzing against several $4 \mathrm{~L}$ changes of PBS, the protein (Lowry et al., 1951) and radioactivity content of each of the peaks were determined as above.

Electrophoresis. In order to assess the integrity of apo B-100, all LDL samples were analyzed by sodium dodecyl sulfate (SDS)-PAGE on 3-20\% acrylamide gradient slab gels essentially as described (Cardin et $a l ., 1986)$. The gels were stained by heating for $2 \mathrm{~h}$ in a solution of $0.1 \%$ Coomassie Blue G-250/50\% acetic acid $/ 10 \%$ methanol, destained in $10 \%$ acetic acid $/ 10 \%$ methanol, and scanned with a Zeineh soft laser scanning densitometer (Biomed Instruments Inc., Fullerton, Calif.).

Fibroblast uptake studies. Cell uptake was examined using both normal human fibroblasts (N-1) and fibroblasts derived from a patient with familial hypercholesteremia (GM-1915, Human Genetic Mutant Cell Repository, Camden, N.J.) as previously described (DeForge et al., 1991). The radiolabelled LDL preparations were added at a concentration of $10 \mu \mathrm{g} / \mathrm{mL}$, and the plates were incubated at $37^{\circ} \mathrm{C}$ for $6 \mathrm{~h}$. Uptake was examined both in the absence and in the presence of a 20 -fold excess of competing native LDL. The cell-associated radioactivity for all samples was determined by counting $\mathrm{NaOH}$ cell digests (DeForge et al., 1991). The media from cells incu- bated with $\left[{ }^{125} 1\right] \mathrm{LDL}$ was analyzed for radioactivity corresponding to degraded apoprotein (Drevon et al., 1981). Total uptake of $\left[{ }^{125} \mathrm{I}\right] \mathrm{LDL}$ (expressed as $\mathrm{ng}$ LDL bound, internalized, and degraded per mg cell protein) was then calculated from the cell-associated radioactivity and the radioactivity in the media corresponding to degraded LDL. Over the $6 \mathrm{~h}$ time period studied, efflux of radiolabeled degradation products from cells incubated with the [ ${ }^{125}$ I]CI-labeled LDL preparations did not occur to a significant extent $(\leqslant 3 \%$ of the total uptake). For these preparations, "ng $\mathrm{LDL} / \mathrm{mg}$ cell protein" represents binding and internalization of the lipoprotein as calculated from cell-associated radioactivity.

\section{Plasma clearance and tissue distribution studies}

Male guinea pigs (450-550 g) were anesthetized with xylazine $(9 \mathrm{mg})$ and ketamine $(30 \mathrm{mg})$, and the right carotid artery of each animal was cannulated essentially as described (Latham, 1977; DeForge et al., 1991). The radiolabeled guinea pig LDL preparations (1.1-8.6 $\mu \mathrm{Ci}$ per animal) were then administered and blood samples $(0.5 \mathrm{~mL})$ were withdrawn via the cannula at $0.25,0.5,1,2,4$ and $6 \mathrm{~h}$ post-injection from conscious, restrained animals (DeForge et al., 1991). The plasma was immediately separated from each blood sample and duplicate aliquots were counted for radioactivity to allow for calculation of the percent injected dose present in the plasma at each time point. Each of the plasma samples was also analyzed in duplicate by electrophoresis on 3\% acrylamide gels (Narayan, 1975). The gels were cut according to the lipoprotein banding pattern (Narayan, 1975) and counted to determine the percent radioactivity co-migrating with the LDL fraction. Animals were killed $24 \mathrm{~h}$ post-injection, and a blood sample was obtained and processed as above. In addition, several tissues were removed and whole organ weights were obtained where appropriate. Duplicate samples of tissue minces were then placed in gelatin capsules, weighed, and counted for radioactivity. From this data, the percent injected dose per gram of tissue was calculated and then multiplied by the weight of the animal in kilograms $[\%(\mathrm{~kg})$ dose $/ \mathrm{g}]$. This expression facilitates comparison between animals by eliminating variability in the data caused by differences in body weights.

\section{Data analysis}

The fractional catabolic rates (FCR) of the guinea pig LDL preparations were calculated using a kinetic model (Langer et al., 1972) originally described by Matthews (1957). Student's $t$-test was used to assess the significance of the differences between the groups.

\section{Results}

\section{Size distribution}

Upon chromatographic analysis using a $6 \%$ agarose column, radioiodinated LDL ([ $\left.\left.{ }^{125} \mathrm{I}\right] \mathrm{LDL}\right)$ 


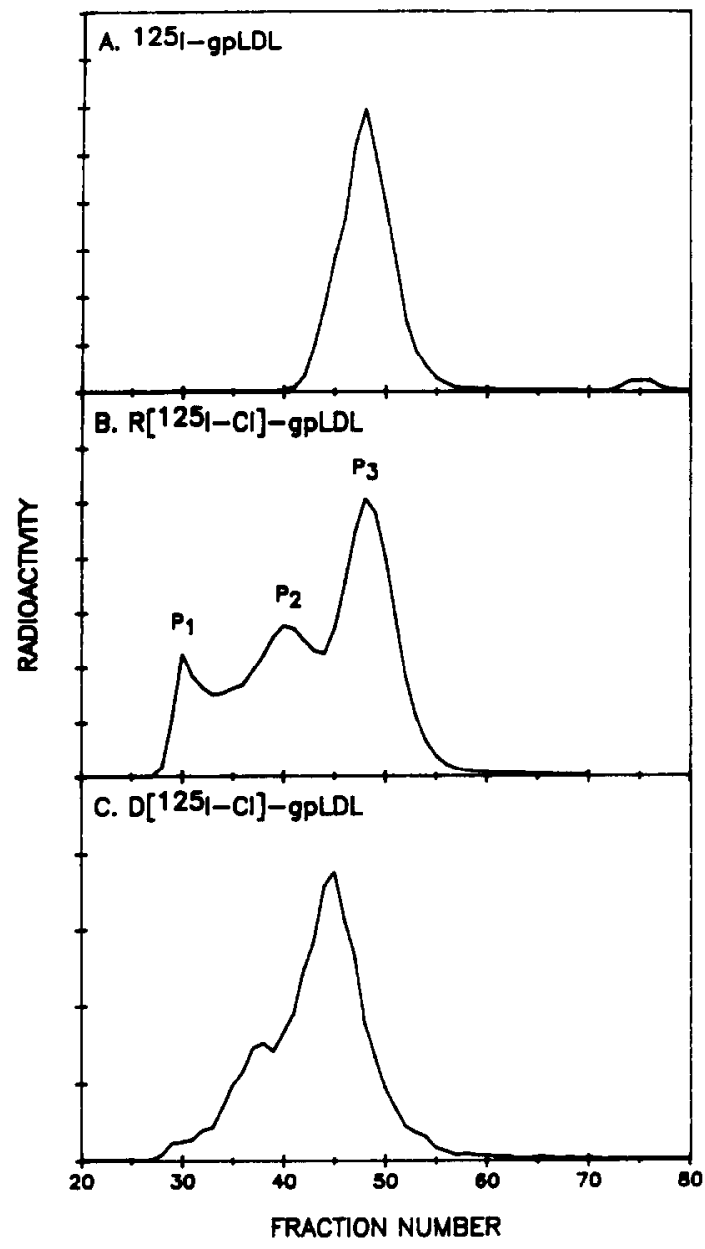

Fig. 2. Elution profiles of $\left[{ }^{125} \mathrm{I}\right] \mathrm{gpLDL}$ (A), R[ [ $\left.{ }^{125} \mathrm{I}-\mathrm{CI}\right]-$ gpLDL (B) and D $\left.{ }^{125} \mathrm{I}-\mathrm{Cl}\right] \mathrm{gpLDL}$ (C) from a gel filtration column of $6 \%$ agarose. The profile of radioactivity is shown and closely corresponded with the u.v. absorbance profile.

eluted as a single, symmetrical peak of protein and radioactivity [Fig. 2(A)]. In contrast, similar analysis of $\mathbf{R}\left[{ }^{125} \mathrm{I}-\mathrm{CI}\right] \mathrm{LDL}$ resolved the preparation into three peaks of protein and radioactivity $\left(\mathrm{P}_{1}, \mathrm{P}_{2}\right.$, and $\left.\mathrm{P}_{3}\right)$ [Fig. 2(B)], which corresponded in size to very low density lipoprotein (VLDL), intermediate density lipoprotein (IDL), and LDL, respectively. The fractions constituting each peak were pooled and concentrated for further analysis. The elution profile of $D\left[{ }^{125} \mathrm{I}-\mathrm{CI}\right] \mathrm{gpLDL}$ showed that this preparation was essentially homogeneous in size, but contained a small shoulder of larger molecular weight material [Fig. 2(C)]. In addition, as compared to the $\left.{ }^{125} \mathrm{I}\right] \mathrm{gpLDL}$ control, the D[25I-CI]gpLDL peak eluted from the column a few fractions earlier than that of $\left[{ }^{125} \mathrm{I}\right] \mathrm{LDL}$, indicating a slight increase in particle size.

\section{Analysis of apo B-100 integrity}

Because it was unclear what effect the labeling procedures had on the integrity of apo B-100, delipidated samples of LDL labeled with $\left[{ }^{125} \mathrm{I}\right] \mathrm{CI}$ by both procedures were analyzed by SDS-PAGE on 3-20\% acrylamide gradient gels. Both preparations were essentially identical to control samples of native LDL and $\left[{ }^{125} \mathrm{I}\right] \mathrm{LDL}$ with respect to the appearance of the apo B-100 band and the absence of bands corresponding to degradation products (data not shown). The three column-derived fractions of the R[ ${ }^{125} \mathrm{I}$ CI]LDL were also analyzed with similar results, thus indicating that neither the reconstitution procedure nor the column fractionation and concentration procedures adversely affected protein integrity.

As a means of assessing the receptor-recognition capability of apo B-100, cell culture studies were conducted in which the uptake of the [ $\left.{ }^{125} \mathrm{I}\right] \mathrm{CI}$-labeled preparations was compared to that of a $\left[{ }^{125} \mathrm{I}\right] \mathrm{LDL}$ control preparation in two lines of human fibroblasts. The $\mathrm{N}-\mathrm{l}$ cell line expresses the LDL receptor and metabolizes LDL normally, while the GM-1915 cell line, obtained from a patient with homozygous familial hypercholesterolemia, does not express the LDL receptor.

The results of one such study are shown in Fig. 3 with uptake of the $\left.{ }^{125} \mathrm{I}\right] \mathrm{CI}$-labeled preparations being expressed as a percentage of the $\left[{ }^{125} \mathrm{I}\right] \mathrm{LDL}$ control. The uptake observed in the $\mathrm{N}-1$ cell line was substantially reduced by the presence of competing LDL, and was similarly low in the LDL receptor-negative cell line (GM-1915). These results indicate that uptake into the normal cells was largely due to an LDL receptor-mediated process. Uptake of $R\left[{ }^{125} \mathrm{I}-\mathrm{CI}\right] \mathrm{LDL}, \mathrm{P}_{3}$, and $\mathrm{P}_{2}$ were not significantly different from that of the $\left.{ }^{[25} \mathrm{I}\right] \mathrm{LDL}$ control, while that of $\mathrm{P}_{\mathrm{I}}$ was lower by approx. $50 \%(P<0.001)$. In this instance, human LDL was used for both the reconstituted LDL preparations and the $\left[{ }^{125} I\right] L D L$ control. Similar results were observed for guinea pig LDL.

Uptake of $D\left[{ }^{125} I-C I\right] g p L D L$ was also examined in the human fibroblast system, and its uptake is expressed as the percentage of a $\left[{ }^{125} \mathrm{I}\right] \mathrm{gpLDL}$ control (Fig. 3). Due to the difference in the species origin of the LDL and the fibroblasts, the uptake of both guinea pig LDL preparations was approx. $60 \%$ lower than that observed for corresponding preparations of human LDL but was nonetheless characteristic of an LDL receptor-mediated process. In this particular experiment, uptake of the $D\left[{ }^{125} I-C I\right] g p L D L$ preparation was slightly higher than that of the ${ }^{[25}$ I] gpLDL control.

\section{Plasma clearance of [ $\left.{ }^{125} I\right] C I$-labeled guinea pig $L D L$}

Each of the $\left[{ }^{125} \mathrm{I}\right] \mathrm{CI}$-labeled guinea pig LDL preparations (R[ $\left[{ }^{125} I-C I\right] g p L D L, P_{1}, P_{2}, P_{3}$, and D ${ }^{125}$ I-CI]gpLDL) was injected into 3-4 normal male guinea pigs, and the plasma levels of radioactivity were assessed at several time points over a $24 \mathrm{~h}$ time period. An additional group of animals was injected with [ $\left.{ }^{125} \mathrm{I}\right] \mathrm{gpLDL}$. The results, expressed as percent injected dose remaining in the plasma, are shown 


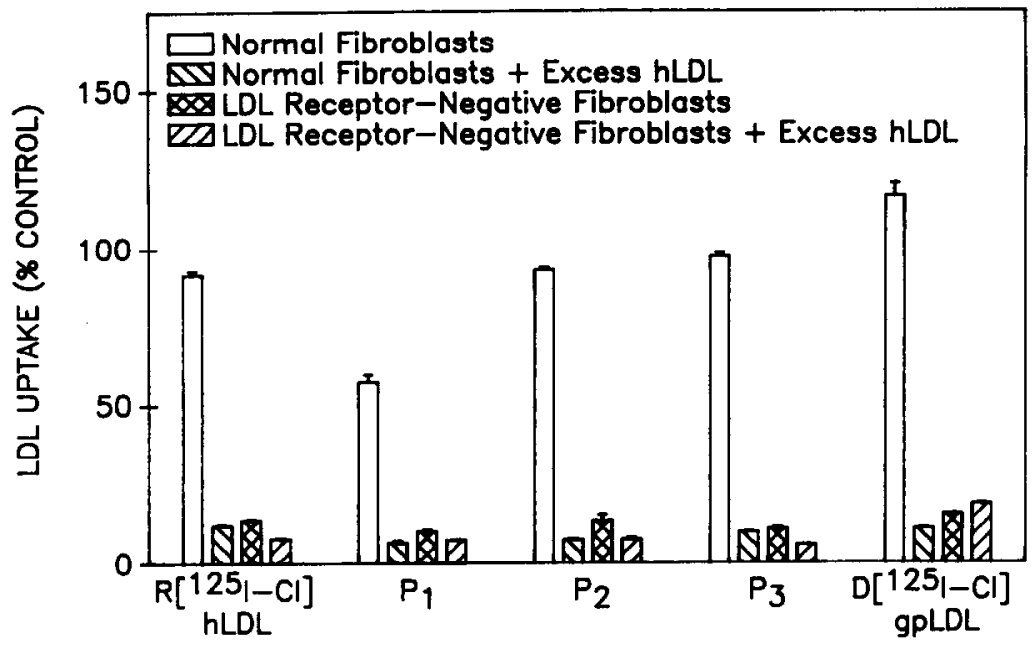

Fig. 3. Fibroblast uptake of R[$\left.{ }^{125} I-C I\right] h L D L, P_{1}, P_{2}, P_{3}$, and D $\left[{ }^{125} I-C I\right] g p L D L$. Both normal (N-1) and LDL receptor-negative (GM-1915) fibroblasts were incubated with each of the lipoprotein preparations at a concentration of $10 \mu \mathrm{g} / \mathrm{mL}$ for $6 \mathrm{~h}$ in the presence and in the absence of $200 \mu \mathrm{g} / \mathrm{mL}$ competing native LDL. Results are expressed as the percent of control uptake (either $\left[{ }^{125} I\right] L D L$ or $\left.\left[{ }^{125} I\right] g p L D L\right)$. The error bars represent the SEM of triplicate determinations.

in Fig. 4. It can be seen that the plasma clearance of $\mathrm{D}\left[{ }^{125} \mathrm{I}-\mathrm{CI}\right] \mathrm{gpLDL}$ was quite similar to that of $\left.{ }^{125} \mathrm{I}\right] \mathrm{gpLDL}$. The FCRs were $0.131 \pm 0.008$ and $0.120 \pm 0.011 \mathrm{~h}^{-1}$ for $\mathrm{D}\left[{ }^{125} \mathrm{I}-\mathrm{CI}\right] \mathrm{gpLDL}$ and $\left.{ }^{125} 1\right] \mathrm{gpLDL}$, respectively (mean \pm SEM). The plasma decay curves of all reconstituted preparations, however, were markedly different. All of these curves were characterized by an initial rapid disappearance of the injected dose from the plasma followed by a rate of clearance which was considerably slower than that of the $\left.{ }^{125} I\right] g p L D L$ control. These abnormalities became more pronounced with increasing particle size. The FCRs of $P_{3}$ and $R\left[^{125} I-C I\right] g p L D L$ were substantially higher than that of $\left[{ }^{125} \mathrm{I}\right] \mathrm{gpLDL}[0.178 \pm 0.032$ and $0.236 \pm 0.062 \mathrm{~h}^{-1}$, respectively (mean \pm SEM)]. FCR values were not calculated for $P_{2}$ and $P_{1}$.

The plasma samples obtained at each time point were also analyzed by $3 \%$ PAGE to determine the distribution of radioactivity in the various lipoprotein fractions. For $\left[{ }^{125} \mathrm{I}\right] \mathrm{gpLDL}, \quad \mathrm{D}\left[{ }^{125} \mathrm{I}\right.$-CI $] \mathrm{gpLDL}$, $\mathrm{R}\left[{ }^{125} \mathrm{I}-\mathrm{CI}\right] \mathrm{gpLDL}$, and $\mathrm{P}_{3}, 70-85 \%$ of the plasma radioactivity at each time point migrated electrophoretically in association with the LDL fraction. For $P_{1}$ and $P_{2}$, this value was somewhat lower $(40-60 \%)$ since a portion of these larger-sized particles migrated in the size range of VLDL and IDL.

\section{Tissue distribution of radioactivity}

All guinea pigs used in the clearance studies were killed $24 \mathrm{~h}$ post-injection, and several tissues were

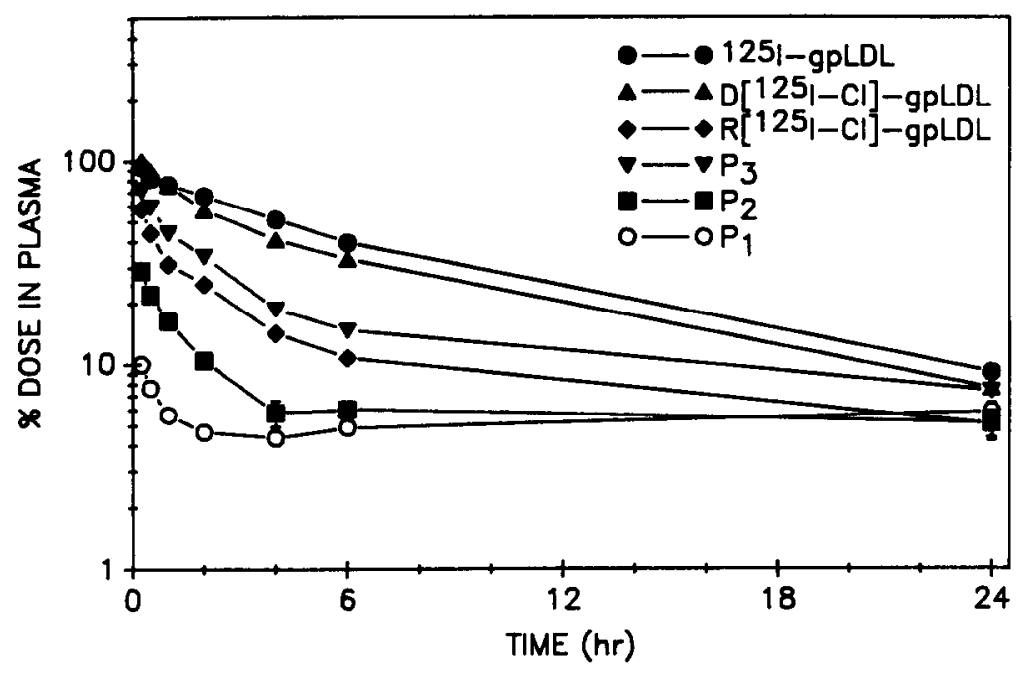

Fig. 4. Time-course of clearance of radioactivity from the plasma of guinea pigs injected with [125 I]gpLDL $(n=4), \mathrm{D}\left[{ }^{125} \mathrm{I}-\mathrm{CI}\right] \mathrm{gpLDL}, \mathrm{R}\left[{ }^{125} \mathrm{I}-\mathrm{C}\right] \operatorname{gpLDL}(n=4), \mathrm{P}_{3}(n=3), \mathrm{P}_{2}(n=3)$, and $\mathrm{P}_{1}(n=3)$. The percent injected dose remaining in the plasma was calculated at each time point, with the values representing mean \pm SEM. 


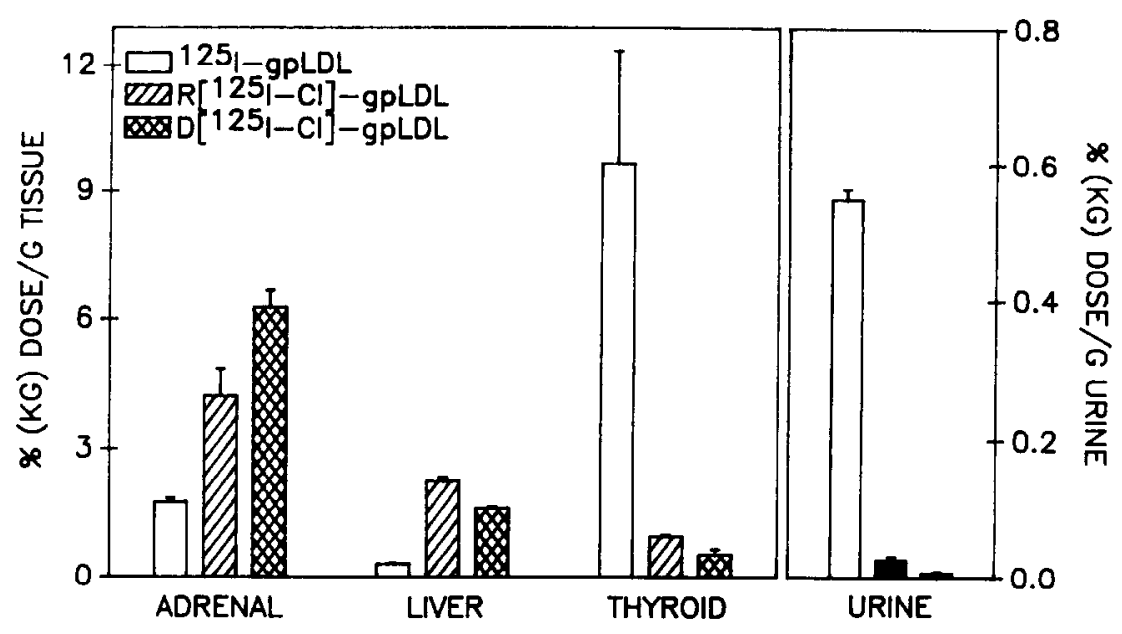

Fig. 5. Tissue distribution of radioactivity in selected tissues $24 \mathrm{~h}$ after injection of guinea pigs with $\left[{ }^{125} \mathrm{I}\right] \operatorname{gpLDL}(n=4), \mathrm{R}\left[{ }^{125} \mathrm{I}-\mathrm{CI}\right] \operatorname{gpLDL}(n=3)$, and D[ $\left.{ }^{125} \mathrm{I}-\mathrm{CI}\right] \mathrm{gpLDL}(n=3)$. The data are expressed as the percent injected dose recovered per gram of tissue multipled by the weight of the animal in kilograms. Values represent mean \pm SEM for the indicated number of animals.

analyzed for radioactivity. These included organs such as heart, lung, spleen, and testes, as well as bile and duodenum (indicative of excretion of free $\left[{ }^{125} 1\right]$ iopanoic acid into the biliary tree), abdominal fat, and skeletal muscle, all of which contained low levels of radioactivity. The major sites of accumulation of radioactivity, however, were the adrenal and liver, tissues expressing the largest numbers of LDL receptors, and the thyroid and urine, sites of accumulation of radioactive degradation products. The results for these tissues are shown in Fig. 5 expressed in terms of \% $(\mathrm{kg})$ dose per gram of tissue. Comparison of the results of the two $\left[^{125} \mathrm{I}\right] \mathrm{CI}$-labeled LDL preparations shows that adrenal radioactivity was higher for the $\mathrm{D}\left[{ }^{125} \mathrm{I}-\mathrm{CI}\right] \mathrm{gpLDL}$ group, while liver radioactivity was higher for the $\mathbf{R}\left[{ }^{125} \mathbf{I}-\mathrm{CI}\right] \mathrm{gpLDL}$ group. These differences were not unexpected considering the more rapid clearance of $\mathrm{R}\left[{ }^{125} \mathrm{I}-\mathrm{CI}\right] \mathrm{gpLDL}$ and the possible contribution of reticuloendothelial cell uptake to the liver radioactivity value. A more striking difference, however, was evident upon comparison of the $\left[{ }^{125} \mathrm{I}\right] \mathrm{CI}$ groups to the group injected with $\left[{ }^{125} \mathrm{I}\right] \mathrm{gpLDL}$. The adrenal and liver radioactivity of the [ $\left.{ }^{125} \mathrm{I}\right] \mathrm{gpLDL}$ group was substantially lower while the thyroid and urine radioactivity was several-fold higher. The tissue distribution of $P_{1}, P_{2}$, and $P_{3}$ was generally similar to that of $\left.R{ }^{125} \mathrm{I}-\mathrm{CI}\right] \mathrm{gpLDL}$ with the exception that adrenal uptake was lower by $22-57 \%$ (data not shown).

\section{Discussion}

Two different procedures for incorporating $\left[{ }^{125} \mathrm{I}\right] \mathrm{CI}$ into LDL were compared for their ability to result in a lipoprotein that is metabolically similar to native LDL both in vitro and in vivo. The first method was a delipidation-reconstitution procedure (Krieger et al., 1978). This method has been successful with a variety of lipophilic molecules (Krieger et al., 1979a, b), it allows the potential for high specific labeling of LDL, and it has been shown to result in a particle similar to native $\mathrm{LDL}$ in vitro (Krieger et al., 1978). An alternative procedure involving incubation of detergent-solubilized $\left[{ }^{125} \mathrm{I}\right] \mathrm{CI}$ with whole plasma was also examined. $\left[{ }^{125} \mathrm{I}\right] \mathrm{CI}$ was readily incorporated into LDL via either method. Although it is not possible to state whether the $\left[{ }^{125} \mathrm{I}\right] \mathrm{CI}$ resides in the lipid core of the LDL preparations resulting from these two procedures, $\left[{ }^{125} \mathrm{I}\right] \mathrm{CI}$ remained firmly associated with the intact LDL molecule when the preparations were subjected to gel filtration chromatography and to electrophoresis on $3 \%$ acrylamide gels. It is known that endogenous CE partition between the surface and core lipids according to their hydrophobicity, and it is reasonable to speculate that this would also be true of $\left[{ }^{125} \mathrm{I}\right] \mathrm{CI}$. Both methods, however, caused some perturbation in the size distribution of the LDL preparation. This was much more severe for the reconstituted LDL and may have resulted from clumping or fusion of the particles during the delipidation procedure. Nonetheless, both $\mathrm{R}\left[{ }^{125} \mathrm{I}-\mathrm{CI}\right] \mathrm{gpLDL}$ and $\mathrm{D}\left[{ }^{125} \mathrm{I}-\mathrm{CI}\right] \mathrm{gpLDL}$ were shown to be suitable for use in in vitro studies in that neither the integrity of apo B-100 nor the extent of receptormediated fibroblast uptake was altered. However, because subtle alterations in LDL may not be detected by in vitro systems (Witztum et al., 1985), in vivo studies were undertaken using the guinea pig as a model of LDL metabolism. This species is well-suited for lipoprotein metabolic studies (Witztum et al., 1985; Luc and Chapman, 1988), with the LDL fraction comprising $70-80 \%$ of the plasma cholesterol (Spady et al., 1983; Sardet et al., 1972).

The results of the plasma clearance study dramatically illustrated the marked differences in the metabolism of the two preparations. While the plasma 
clearance rates of the $R\left[{ }^{125} \mathrm{I}-\mathrm{CI}\right] \mathrm{gpLDL}$ preparation and the chromatographically-separated size fractions were markedly abnormal, the clearance rate of $\left.D{ }^{125} \mathrm{I}-\mathrm{Cl}\right] \mathrm{gpLDL}$ was not significantly different from that of the $\left[{ }^{125} \mathrm{I}\right] \mathrm{gpLDL}$ control. Furthermore, the advantage of using LDL labeled with a residualizing tracer such as $\left[{ }^{125} \mathrm{I}\right] \mathrm{CI}$ as opposed to radioiodinated LDL was readily apparent from the results of the tissue distribution study. In previous studies in which saline-solubilized $\left.{ }^{125} \mathrm{I}\right] \mathrm{CI}$ was injected into guinea pigs, TLC analysis of extracts of adrenal and liver samples demonstrated that greater than $80 \%$ of the radioactivity was still associated with the parent compound $24 \mathrm{~h}$ post-injection (unpublished results). The longterm stability of $\left.{ }^{125} \mathrm{I}\right] \mathrm{CI}$ in other species has also been documented (DeForge et al., 1989; DeGalan et al., 1986; Seevers et al., 1982). Moreover, the low levels of thyroid and urine radioactivity demonstrated that the compound, with the radioiodine placed on an aromatic group, was also quite resistant to deiodination.

In conclusion, $\left.\mathrm{D}{ }^{125} \mathrm{I}-\mathrm{CI}\right] \mathrm{gpLDL}$ represents a suitable probe for tracing uptake of LDL-associated CE in guinea pigs. This preparation has potential applications for studying the changes in the sites of CE uptake accompanying hypo- and hypercholesterolemia, adrenal dysfunction, and atherosclerosis.

Acknowledgements - The authors gratefully acknowledge the expert technical advice and instruction of $\mathrm{Dr}$ Thomas Bocan, Ms Erika Ferguson, Ms Karen Kieft, Ms Catherine Sekerke, and $\mathrm{Mr}$ Paul Uhlendorf. This research was supported by grants from the National Institutes of Health (CA-08349), the American Heart Association of Michigan, and by a National Institutes of Health Pharmacological Sciences Training Grant (T32-07767).

\section{References}

Cardin A. D., Price C. A., Hirose N., Krivanek M. A., Blankenship D. T., Chao J. and Mao S. J. T. (1986) Structural organization of apolipoprotein B-100 of human plasma low density lipoproteins. Comparsion to B-48 of chylomicrons and very low density lipoproteins. J. Biol. Chem. 261, 16,744-16,748.

Counsell R. E., Schwendner S. W., Gross M. D., Longino M. A. and McConnell D. S. (1989) Lipoprotein incorporation enhances radioiodinated cholesteryl ester uptake into steroid hormone-secreting tissues. J. Nucl. $\mathrm{Med}$. 30, 1088-1094.

DeForge L. E., Ruyan M. K., Schwendner S. W., Newton R. S. and Counsell R. E. (1991) Synthesis and evaluation of radioiodinated cholesteryl ethers as lipoprotein probes. Bioconjug. Chem. 2, 254-260.

DeForge L. E., Schwendner S. W., DeGalan M. R., McConnell D. S. and Counsell R. E. (1989) Noninvasive assessment of lipid disposition in treated and untreated atherosclerotic rabbits. Pharmaceut. Res. 6, 1011-1016.

DeGalan M. R., Schwendner S. W., Gross M. D. and Counsell R. E. (1985) Assessment of the antiatherogenic efficacy of a hypolipidemic drug by scintigraphy. In Current Applications in Radiopharmacology. Proceedings of the Fourth International Symposium on Radiopharmacology (Edited by Billinghurst M. W.), pp. 109-117. Pergamon Press, New York.

DeGalan M. R., Schwendner S. W., Weichert J. P. and Counsell R. E. (1986) Radioiodinated cholesteryl iopanoate as a potential probe for the in vivo visualization of atherosclerotic lesions in animals. Pharmaceut. Res. 3, $52-55$.

DeGalan M. R., Schwendner S. W., Skinner R. W., Longino M. A., Gross M. D. and Counsell R. E. (1988) Iodine-125 cholesteryl iopanoate for measuring extent of atherosclerosis in rabbits. J. Nucl. Med. 29, 503-508.

Drevon C. A., Attie A. D., Pangburn S. H. and Steinberg D. (1981) Metabolism of homologous and heterologous lipoproteins by cultured rat and human skin fibroblasts. J. Lipid Res. 22, 37-46.

Edelstein C. and Scanu A. M. (1986) Precautionary measures for collecting blood destined for lipoprotein isolation. Methods Enzymol. 128, 151-155.

Fischman A. J., Lees A. M., Lees R. S., Barlai-Kovach M. and Strauss H. W. (1987) Accumulation of native and methylated low density lipoproteins by healing rabbit arterial wall. Arteriosclerosis 129, 361-366.

Goldstein J. L. and Brown M. S. (1977) The low-density lipoprotein pathway and its relation to atherosclerosis. Ann. Rev. Biochem. 46, 897-930.

Goldstein J. L., Basu S. K. and Brown M. S. (1983) Receptor-mediated endocytosis of low-density lipoprotein in cultured cells. Methods Enzymol. 98, 241-260.

Guo L. S. S., Meng M., Hamilton R. L. and Ostwald R. (1977) Changes in the plasma lipoprotein-apoproteins of guinea pigs in response to dietary cholesterol. Biochemistry 16, 5806-5812.

Halperin G., Stein O. and Stein Y. (1986) Synthesis of ether analogs of lipoprotein lipids and their biological application. Methods Enzymol. 129, 816-848.

Havel R. J., Eder H. A. and Bragdon J. H. (1955) The distribution and chemical composition of ultracentrifugally separated lipoproteins in human serum. J. Clin. Invest. 34, 1345-1353.

Krieger M., Brown M. S., Faust J. R. and Goldstein J. L. (1978) Replacement of endogenous cholesteryl esters of low density lipoprotein with exogenous cholesteryl linoleate. Reconstitution of a biologically active particle. J. Biol. Chem. 253, 4093-4101.

Krieger M., McPhaul M. J., Goldstein J. L. and Brown M.S. (1979a) Replacement of neutral lipids of low density lipoproteins with esters of long chain unsaturated fatty acids. J. Biol. Chem. 254, 3845-3853.

Krieger M., Smith L. C., Anderson R. G. W., Goldstein J. L., Kao Y. J., Pownall H. J., Gotto A. M. Jr and Brown M. S. (1979b) Reconstituted low density lipoprotein: a vehicle for the delivery of hydrophobic fluorescent probes to cells. J. Supramol. Struct. 10, 467-478.

Langer T., Strober W. and Levy R. I. (1972) The metabolism of low density lipoprotein in familial type II hyperlipoproteinemia. J. Clin. Invest. 51, 1528-1536.

Latham A. N. (1977) A new chronically cannulated carotid artery preparation for determination of drug half-lives in guinea pig. Can. J. Physiol. Pharmacol. 55, 773-777.

Lees R. S., Garabedian H. D., Lees A. M., Schumacher D. J., Miller A., Isaacsohn J. L., Derksen A. and Strauss H. W. (1985) Technetium-99m low density lipoproteins: preparation and biodistribution. J. Nucl. Med. 26, 1056-1062.

Lowry O. H., Rosebrough N. J., Farr A. L. and Randall R. J. (1951) Protein measurement with the Folin phenol reagent. J. Biol. Chem. 193, 265-275.

Luc G. and Chapman M. J. (1988) Guinea pig low density lipoproteins: structural and metabolic heterogeneity. J. Lipid Res. 29, 1251-1263.

Matthews C. M. E. (1957) The theory of tracer experiments with ${ }^{13 !}$ I-labelled plasma proteins. Phys. Med. Biol. 2, 36-53.

Narayan K. A. (1975) Electrophoretic methods for the separation of serum lipoproteins. In Analysis of Lipids and Lipoproteins (Edited by Perkins E. G.), pp. 225-249. The American Oil Chemists Society, Champaign, Ill. 
Pittman R. C., Carew T. E., Glass C. K., Green S. R., Taylor C. A. and Attie A. D. (1983) A radioiodinated, intracellularly trapped ligand for determining the sites of plasma protein degradation in vivo. Biochem. J. 212, $791-800$.

Rudel L. L., Lee J. A., Morris M. D. and Felts J. M. (1974) Characterization of plasma lipoproteins separated and purified by agarose-column chromatography. Biochem. $J$. 139, 89-95.

Sardet C., Hansma H. and Ostwald R. (1972) Characterization of guinea pig plasma lipoproteins: the appearance of new lipoproteins in response to dietary cholesterol. J. Lipid Res. 13, 624-639.
Seevers R. H., Groziak M. P., Weichert J. P., Schwendner S. W., Szabo S. M., Longino M. A. and Counsell R. E. (1982) Potential tumor- or organ-imaging agents. 23. Sterol esters of iopanoic acid. J. Med. Chem. 25, $1500-1503$.

Spady J. M. and Dietschy J. M. (1983) Sterol synthesis in vivo in 18 tissues of the squirrel monkey, guinea pig, rabbit, hamster, and rat. J. Lipid Res. 24, 303-315.

Witztum J. L., Young S. G., Elam R. L., Carew T. E. and Fisher M. (1985) Cholestyramine-induced changes in low density lipoprotein composition and metabolism. I. Studies in the guinea pig. J. Lipid Res. 26, 92-103. 